\title{
Studies on the virulence of Aerococcus viridans (var.) homari, the causative agent of gaffkemia, a fatal disease of homarid lobsters
}

\author{
James E. Stewart, John W. Cornick, B. M. Zwicker, B. Arie \\ Science Branch, Department of Fisheries and Oceans, Bedford Institute of Oceanography, PO Box 1006, Dartmouth, \\ Nova Scotia B2Y 4A2, Canada
}

\begin{abstract}
Virulent and avirulent strains of Aerococcus viridans (var.) homari were used to extend previous studies to determine and confirm differences between the 2 types. Virulent strains possessed polysaccharide capsules and were not agglutinated by lobster hemolymph serum; avirulent strains did not have capsules, were agglutinated by the lobster hemolymph serum, and most did not grow well in lobster hemolymph serum. Growth of the avirulent strains in sterile lobster hemolymph serum induced the production of capsules (which reached a maximum after 5 to $7 \mathrm{~d}$ incubation), eliminated susceptibility of the strains to the lobster serum agglutinin, and restored their virulence against lobsters. The factor(s) in lobster hemolymph serum inducing the long-lasting phenotypic response of virulence was (were) heat labile.
\end{abstract}

KEY WORDS: Lobster · Homarus americanus · Virulence · Aerococcus viridans (var.) homari • Capsules · Agglutinin

Resale or republication not permitted without written consent of the publisher

\section{INTRODUCTION}

Information on infectious diseases of lobsters has been concentrated mainly on representatives of the genus Homarus, because the industry surrounding it involves primarily the sale of living animals. Consequently, live lobsters are held for varying periods under conditions ranging from adequate to completely unsatisfactory. In addition to the health threats posed by these forms of captivity are those stemming from attempts to culture lobsters; all of these activities have forced studies on lobster diseases that are more extensive than the studies on the diseases of many other invertebrates. Reviews of in-depth studies on gaffkemia, the overwhelming systemic infection of lobsters caused by the free-living, gram positive, tetrad-forming coccus, Aerococcus viridans (var.) homari (previously Gaffkya homari), include those by Stewart \& Rabin (1970), Fisher et al. (1978), Sparks (1981), Stewart (1984, 1993), Sindermann \& Lightner (1988), and Sindermann (1990) among others.
Questions regarding the virulence of Aerococcus viridans (var.) homari arose early in surveys conducted to determine its prevalence among wild populations of the lobster Homarus americanus. Stewart et al. (1966) recorded infection levels ranging from 1.7 to $40 \%$, and in addition to those surveys, ran trials to determine the extent to which lobsters possessing bacteria identified as A. viridans (var.) homari actually developed fullblown infections resulting in deaths. Twelve of 28 lobsters that were confirmed as infected survived, and showed no evidence of $A$. viridans (var.) homari in their hemolymph when tested by cultural methods 4 mo later. Although misidentification of some of the bacteria might explain part of these findings, avirulence among the various strains was also a distinct possibility. This aspect was explored further when strains of A. viridans (var.) homari of proven avirulence became available.

Preliminary studies (Stewart 1984), performed to detect differences between virulent and avirulent strains, indicated that virulent strains were not aggluti- 
nated by the lobster serum agglutinins, while avirulent strains were. Additionally, $24 \mathrm{~h}$ growth trials showed that virulent strains formed substantial capsules when grown in lobster hemolymph serum, while under the same time and conditions avirulent strains produced only trace amounts of capsular materials.

In this paper we report extensions of these investigations conducted to determine the degrees of variation in virulence among different strains of Aerococcus viridans (var.) homari, the coincidence of capsular materials with virulence, the stability of virulence and its restoration.

\section{MATERIALS AND METHODS}

Lobsters. Freshly captured lobsters of both sexes (weighing between 450 and $500 \mathrm{~g}$ ) were obtained directly from fishermen in Eastern Passage and Digby, Nova Scotia. The chelae were immobilized with heavy rubber bands and the lobsters were held in tanks supplied with running, filtered seawater at ambient temperatures ranging from 1 to $12^{\circ} \mathrm{C}$, depending upon season. All experimental work was carried out in tanks of re-circulating, filtered seawater at $15 \pm 0.5^{\circ} \mathrm{C}$ after the lobsters had been acclimated to this temperature for ca. 2 wk; the lobsters were not fed during the actual challenge trials. Individual shelters were provided in tanks to protect the lobsters during holding periods and experimental work. Prior to the initiation of experiments, all lobsters involved were examined by culture methods and hemolymph smears (Stewart et al. 1966) to ensure that they were not infected with Aerococcus viridans (var.) homari.

Strains of Aerococcus viridans (var.) homari. Strains were isolated during various surveys and identified as described by Stewart et al. (1966), or purchased from the American Type Culture Collection (ATCC 10400); 1 strain of proven virulence, which we have used for reference purposes throughout much of the work on this disease, was donated by Dr. H. Rabin (hereafter referred to as Rabin's strain; Cornick \& Stewart 1968). The virulence of Rabin's strain was maintained by serial passage through lobsters held at $15^{\circ} \mathrm{C}$ (Cornick \& Stewart 1968). For experimental infection purposes, $0.2 \mathrm{ml}$ of hemolymph was removed from a lobster infected with Rabin's strain and transferred to $5 \mathrm{ml}$ trypticase soy broth (TSB) (Baltimore Biological Laboratories) and grown at $28^{\circ} \mathrm{C}$ for $24 \mathrm{~h}$.

Sterile lobster hemolymph serum. Based on the procedure of Lauffer \& Swaby (1955), hemolymph drawn from the ventral abdominal sinus was allowed to form a non-retracting, firm, hard clot. The clot was broken up with a stirring rod and centrifuged at $30000 \times g$ for $20 \mathrm{~min}$; the supernatant fluid was passed through coarse filter paper at $5^{\circ} \mathrm{C}$ and then sterilized by membrane filtration $\left(0.45 \mu \mathrm{m}\right.$ pore size) and stored at $4^{\circ} \mathrm{C}$ for use within $7 \mathrm{~d}$ (Cornick \& Stewart 1968, 1973).

Agglutination. Standard tube agglutination tests employing serial 2-fold dilutions were performed with freshly prepared serum. A 24 h culture of Brevibacterium sp. (27), originally isolated from lobster hemolymph (Cornick \& Stewart 1966), was used to prepare suspensions in $3 \% \mathrm{NaCl}$ solution standardized to correspond with the McFarland Turbidity Scale 2 (Kabat \& Mayer 1961). The Brevibacterium sp. suspension was chosen as the standard for the agglutination tests because lobster hemolymph serum showed the highest titre against this organism. The tubes were incubated at $25^{\circ} \mathrm{C}$ for $24 \mathrm{~h}$ to determine the titre. Agglutination results are reported as reciprocals of the dilutions.

Adsorption. Sterile lobster hemolymph serum was examined to determine whether the serum agglutinins could be removed by adsorption with the live Rabin's strain, and/or ATCC 10400 grown for $24 \mathrm{~h}$ at $28^{\circ} \mathrm{C}$ in TSB and then washed 3 times with sterile $3 \% \mathrm{NaCl}$ solution. The bacteria ( $2 \%$ packed cell volume) were incubated in the hemolymph serum for $1 \mathrm{~h}$ at $25^{\circ} \mathrm{C}_{\text {; }}$ they were then removed by centrifugation $(30000 \times g$ for $10 \mathrm{~min}$ at $4^{\circ} \mathrm{C}$ ) followed by membrane filtration ( $0.45 \mu \mathrm{m}$ pore size) of the serum. The adsorbed serum was then used in agglutination trials against Brevibacterium sp. (27), ATCC 10400 and rabbit red-blood cells ( $1 \%$ in sterile $3 \% \mathrm{NaCl}$ ).

Challenges. For challenges of groups of lobsters, bacteria prepared for injection were grown in TSB for $24 \mathrm{~h}$ at $28^{\circ} \mathrm{C}$, harvested and washed 3 times with sterile $3 \% \mathrm{NaCl}$ solution, and standardized spectrophotometrically to 0.1 or 0.2 optical density (OD) at $420 \mathrm{~nm}$ (approximately 1 or $2 \times 10^{6}$ bacteria $\mathrm{ml}^{-1}$, respectively); the numbers of colony forming units (cfu) were confirmed by plate counts. The bacteria were injected into the ventral abdominal sinus of individual lobsters, usually at ca. $1 \times 10^{6} \mathrm{cfu} \mathrm{kg} \mathrm{BW}^{-1}$ (lobster body weight) and the lobsters were examined several times daily. The injection site was swabbed with a $70 \%$ ethanol solution before and after injections. A parallel set of control lobsters injected with the same volumes of a sterile $3 \%$ $\mathrm{NaCl}$ solution was always exposed to the same conditions for the full period of the trial. Lobsters that died in these trials were removed and examined by hemolymph smears and/or culture methods to determine the cause of death. Dead lobsters shown to be heavily infected with the pathogen were used to calculate the mean time to death (MTD) in days. Very occasionally in some trials a control lobster would die; none of these deaths, however, could be attributed to gaffkemia.

Capsules. Slides made from bacterial cultures prepared using standard blood-smear procedures were air-dried and then stained using a procedure for poly- 
saccharide staining adapted from Pearse (1961). Briefly, alcian blue (1\% in $3 \%$ acetic acid) was applied for $15 \mathrm{~min}$, the slide was then washed with distilled water, drained and counterstained with $1 \%$ aqueous neutral red for 1 min, washed again, and blotted dry. The bacterial bodies, occurring in tetrads, pairs and singly, stained red; capsules, when present, surrounded the bacteria in a blue-green band. Capsule and bacterial sizes were determined microscopically using oil immersion (magnification 1000x) and a calibrated eyepiece. The overall width of the tetrad (capsule layer plus bacteria) was measured on a line through the bacteria at the point where they were attached. The bacterial widths were then deducted and the capsule widths reported as the shortest distances between the edge of the bacterial cell and the outer edge of the layer staining blue-green, e.g. overall tetrad width of $1.66 \mu \mathrm{m}$ minus the total bacterial width of $1.0 \mu \mathrm{m}$ leads to: $1.66-1.0=0.66 / 2=0.33 \mu \mathrm{m}$ (individual capsule width).

\section{RESULTS}

Ten strains of Aerococcus viridans (var.) homari from a southern New Brunswick large holding facility for live lobsters proved to be virulent to healthy lobsters when used within $2 \mathrm{wk}$ of their isolation (Fig. 1). The MTDs ranged from a low of $8.8 \mathrm{~d}$ to an MTD of $23.8 \mathrm{~d}$;

Table 1. Lobsters Homarus americanus challenged at $15^{\circ} \mathrm{C}$ with the Aerococcus viridans (var.) homari strains listed in Fig. 1 after maintenance in trypticase soy broth for 3 yr. Data are for periods when (A) all 10 of the challenged lobsters died, and (B) some or all of the 10 challenged lobsters survived the $92 \mathrm{~d}$ observation period. All challenged animals that died exhibited a heavy infection with $A$. viridans (var.) homari. None of the animals surviving the $92 \mathrm{~d}$ observation period were shown to have the pathogen in their hemolymph. MTD: mean time to death

\begin{tabular}{|lcc|}
\hline (A) Strain no. & $\begin{array}{c}\text { No. surviving } \\
\text { out of } 10\end{array}$ & $\begin{array}{c}\text { MTD } \pm \text { SE } \\
\text { (d) }\end{array}$ \\
\hline 8 & 0 & $30.7 \pm 2.9$ \\
14 & 0 & $23.5 \pm 3.4$ \\
16 & 0 & $26.6 \pm 8.0$ \\
17 & 0 & $21.2 \pm 3.15$ \\
Rabin's strain & 0 & $28.7 \pm 7.3$ \\
& & \\
(B) Strain no. & No. surviving & MTD \pm SE, based on \\
& out of 10 & no. dead lobsters (d) \\
\hline 11 & 5 & $41.8 \pm 10.9$ \\
13 & 2 & $34.6 \pm 3.4$ \\
15 & 4 & $47.0 \pm 6.4$ \\
18 & 6 & $33.0 \pm 5.5$ \\
19 & 10 & \\
\hline
\end{tabular}

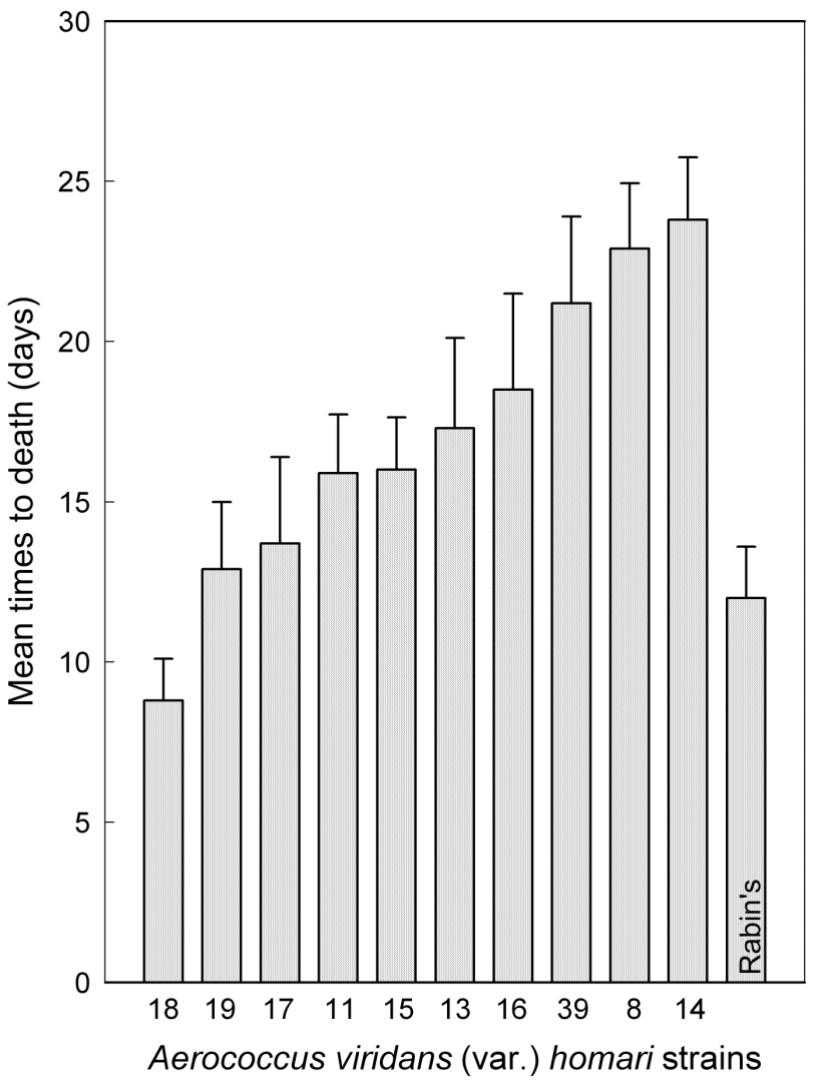

Fig. 1. Homarus americanus. Challenge at $15^{\circ} \mathrm{C}$ of lobsters with recently isolated strains of Aerococcus viridans (var.) homari compared with the reference strain (Rabin's), the virulence of which had been maintained by lobster passage. Each bar represents the mean time to death (MTD) \pm SE for a group of 10 lobsters; all challenged individuals died exhibiting heavy A. viridans (var.) homari infections

the MTD obtained with Rabin's reference strain, whose virulence had been maintained by lobster passage, was $12 \mathrm{~d}$.

Subsequently, all of the strains listed in Fig. 1 were maintained at $28^{\circ} \mathrm{C}$ by approximately weekly transfers using parallel trypticase soy agar (TSA) and TSB to ensure perpetuation of the cultures and to permit cross-checking of the cultures' purity. Three yr later, the virulence of each of those grown in TSB, except Strain 39, was tested again using the identical protocol, and the results were compared with those in Fig 1. The results of this second challenge (Table 1) were substantially different from those of the first challenge performed shortly after the isolation of these bacteria. The virulence of all strains except 14 had declined as shown by the extensions of the MTD; 4 strains $(11,13$, 15 and 18) no longer caused the death of all animals challenged, while Strain 19 had become avirulent, as shown by the complete absence of the pathogen in the animals surviving the $92 \mathrm{~d}$ observation period. 


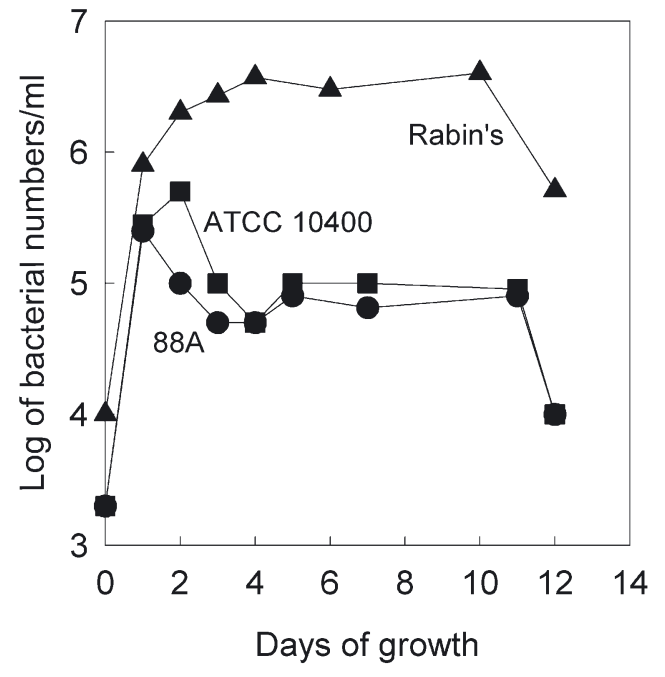

Fig. 2. Aerococcus viridans (var.) homari. Growth of virulent (Rabin's) and avirulent strains (American Type Culture Collection [ATCC] 10400 and 88A) in normal lobster Homarus americanus hemolymph serum incubated at $28^{\circ} \mathrm{C}$

Several other strains, isolated in earlier surveys and carried along with the ATCC 10400 strain of Aerococcus viridans (var.) homari in laboratory medium (TSB) for 5 to $6 \mathrm{yr}$, were examined for virulence using the standard challenge procedures against groups of 10 lobsters each. Strains 88A, 88B, 37R and ATCC 10400 failed to cause deaths or infections over a $52 \mathrm{~d}$ period and thus were declared avirulent. Two of these strains (88A and ATCC 10400) plus Rabin's strain were each used to inoculate $10 \mathrm{ml}$ quantities of sterile lobster hemolymph serum, which were incubated at $28^{\circ} \mathrm{C}$. One $\mathrm{ml}$ aliquots were removed at zero time and the intervals indicated to measure bacterial growth (Fig. 2) and capsule widths (Table 2). Growth of the avirulent strains, as gauged by total bacterial yields, was much

Table 2. Aerococcus viridans (var.) homari. Mean capsule widths $(\mu \mathrm{m})$ for strains grown in lobster Homarus americanus serum at $28^{\circ} \mathrm{C}$. ATCC: American Type Culture Collection. $\mathrm{N}$ = number of capsule measurements made for that day for this particular A. viridans (var.) homari strain

\begin{tabular}{|c|c|c|c|c|c|c|}
\hline \multirow[t]{2}{*}{$\begin{array}{l}\text { Days of } \\
\text { growth }\end{array}$} & \multirow{2}{*}{\multicolumn{2}{|c|}{$\begin{array}{c}\text { 88A } \\
\mathrm{N} \quad \text { Capsule widths } \\
\pm \mathrm{SE}\end{array}$}} & \multicolumn{2}{|r|}{$\begin{array}{l}\text { Strain }- \\
\text { ATCC } 10400\end{array}$} & \multicolumn{2}{|r|}{ Rabin } \\
\hline & & & $\mathrm{N}$ & $\begin{array}{c}\text { Capsule widths } \\
\pm \mathrm{SE}\end{array}$ & $\mathrm{N}$ & $\begin{array}{c}\text { Capsule widths } \\
\pm \mathrm{SE}\end{array}$ \\
\hline 0 & 25 & none detectable & 25 & trace & 25 & $0.31 \pm 0.04$ \\
\hline 1 & 25 & $0.15 \pm 0.03$ & 25 & $0.13 \pm 0.03$ & 25 & $0.11 \pm 0.02$ \\
\hline 2 & 25 & $0.28 \pm 0.04$ & 25 & $0.21 \pm 0.03$ & 25 & $0.15 \pm 0.03$ \\
\hline 3 & 25 & $0.37 \pm 0.03$ & 25 & $0.39 \pm 0.04$ & - & - \\
\hline 4 & 25 & $0.37 \pm 0.04$ & 25 & $0.33 \pm 0.03$ & 25 & $0.36 \pm 0.04$ \\
\hline 5 & 25 & $0.36 \pm 0.04$ & 25 & $0.43 \pm 0.03$ & - & - \\
\hline 7 & 25 & $0.43 \pm 0.03$ & 25 & $0.41 \pm 0.03$ & 25 & $0.25 \pm 0.03$ \\
\hline 11 & 25 & $0.40 \pm 0.04$ & 25 & $0.35 \pm 0.04$ & 25 & $0.27 \pm 0.02$ \\
\hline
\end{tabular}

poorer than that exhibited by Rabin's strain. The capsule widths for Rabin's strain were substantial throughout, those for strains ATCC 10400 and 88A increased gradually from zero, reaching a maximum by the Days 5 and 7 respectively (see Table 2 ).

In a further trial, these strains (88A, ATC 10400, Rabin's) were transferred to sterile lobster hemolymph serum for $7 \mathrm{~d}$ at $28^{\circ} \mathrm{C}$. These serum-grown cultures were used for measuring capsule widths at 0 and $7 \mathrm{~d}$; the $7 \mathrm{~d}$ growth was then used to prepare inocula to challenge lobsters. The results of both determinations (Table 3) show that the previously avirulent Strains 88A and ATCC 10400 now had well-developed capsules and were virulent as a result of growth in normal lobster hemolymph serum. The infective agent was then recovered from one of the lobsters that died during this trial as a result of injection with Strain ATCC 10400. This culture was grown in TSB for 8 and 16 further weekly transfers and used in 2 challenges (1 after 8 weekly transfers and 1 after 16 weekly transfers) in an attempt to determine the short-term effects of serial passage in laboratory medium. The results are given in Table 4 ; the restored virulence did not diminish or change significantly $\left(F_{27,2}=0.77, \mathrm{p}=0.47\right.$; Snedecor \& Cochran 1973) over the course of 16 passages in TSB.

Data additional to that, reported by Stewart (1984) on lobster serum agglutinins, confirmed that the virulent strains were not agglutinated, while avirulent strains were. Aerococcus viridans (var.) homari Strains $18,19,11,15,13,16,8,14$, and Rabin's strain, all of proven virulence (see Fig. 1), had fully developed capsules and were not agglutinated in trials with normal lobster hemolymph serum, which had an agglutinin titre of 64 when tested against the avirulent Strains 88A, 88B, 37R and ATCC 10400. Further proof that the agglutination varies inversely with virulence was obtained with 2 cultures of Rabin's strain, one of which became avirulent following 2 yr in lyophilization, and the other after prolonged maintenance in thioglycollate broth. When these 2 strains were tested against normal lobster serum they were agglutinated at titres of 256 and 128 respectively. After recovery of virulence as a result of lobster passage, both strains were negative for agglutination by a lobster hemolymph serum preparation, with a titre of 8 , when measured against the Brevibacterium reference strain.

Although virulent strains of Aerococcus viridans (var.) homari were not agglutinated by lobster serum, the 
Table 3. (A) Aerococcus viridans (var.) homari. Mean capsule widths ( $\mu \mathrm{m})$ for strains grown in lobster Homarus americanus serum at $28^{\circ} \mathrm{C}$. (B) H. americanus. Mean time to death (MTD) at $15^{\circ} \mathrm{C}$ for 3 groups of 10 lobsters each challenged with suspensions of bacteria prepared from cultures in (A) on Day 7. All challenged lobsters died, exhibiting heavy infections with $A$. viridans (var.) homari. $\mathrm{N}=$ number of capsule measurements made for that day for this particular $A$. viridans (var.) homari strain. ATCC: American Type Culture Collection

\begin{tabular}{|c|c|c|c|c|c|c|}
\hline \multirow{3}{*}{$\begin{array}{l}\text { (A) Growth } \\
\text { (d) }\end{array}$} & \\
\hline & \multicolumn{2}{|r|}{$88 \mathrm{~A}$} & \multicolumn{2}{|c|}{ ATCC 10400} & \multicolumn{2}{|r|}{ Rabin } \\
\hline & $\mathrm{N}$ & Width $\pm \mathrm{SE}$ & $\mathrm{N}$ & Width \pm SE & $\mathrm{N}$ & Width \pm SE \\
\hline 0 & $25 \mathrm{r}$ & one detectable & 25 & tone detectable & 25 & $0.27 \pm 0.02$ \\
\hline 7 & 25 & $0.33 \pm 0.04$ & 25 & $0.30 \pm 0.03$ & 25 & $0.33 \pm 0.04$ \\
\hline \multicolumn{3}{|c|}{ (B) A. viridans (var.) homari strain } & \multicolumn{4}{|c|}{$\mathrm{MTD}(\mathrm{d})$ at $15^{\circ} \mathrm{C} \pm \mathrm{SE}$} \\
\hline \multirow{3}{*}{\multicolumn{3}{|c|}{$\begin{array}{l}\text { 88A } \\
\text { ATCC } 10400 \\
\text { Rabin }\end{array}$}} & \multicolumn{4}{|c|}{$17.7 \pm 2.9$} \\
\hline & & & \multicolumn{4}{|c|}{$20.9 \pm 4.4$} \\
\hline & & & \multicolumn{4}{|c|}{$7.7 \pm 1.2$} \\
\hline
\end{tabular}

membrane filtration $(0.45 \mu \mathrm{m}$ pore size). These strains were then incubated in the heated serum and transferred 3 times in the sterile heated lobster serum at $4 \mathrm{~d}$ intervals. These actively growing cultures were then transferred to TSB for $24 \mathrm{~h}$ and used to prepare live cell suspensions in $3 \%$ $\mathrm{NaCl}$ for injection into live lobsters $\left(88 \mathrm{~A}, 1.5 \times 10^{6} \mathrm{cfu} \mathrm{ml}^{-1} ; 88 \mathrm{~B}, 1.7 \times 10^{6}\right.$ cfu ml ${ }^{-1}$; ATCC, $3.3 \times 10^{6} \mathrm{cfu} \mathrm{ml}^{-1}$; $37 \mathrm{R}$, $2 \times 10^{6} \mathrm{cfu} \mathrm{m} \mathrm{ml}^{-1}$ ). Each strain was injected into 10 lobsters at the rate of $1 \mathrm{ml} \mathrm{kg} \mathrm{BW}^{-1}$. In the $42 \mathrm{~d}$ trial at $15^{\circ} \mathrm{C}$ only 1 lobster died; examination of this individual by hemolymph smear and TSB culture failed to show Aerococcus viridans (var.) homari in its hemolymph. Examination of all sur-

Table 4. Homarus americanus. Mean time to death (MTD) \pm $\mathrm{SE}$ (at $15^{\circ} \mathrm{C}$ ) for each group of 10 lobsters challenged with Aerococcus viridans (var.) homari American Type Culture Collection (ATCC) 10400 following restoration of virulence and subsequent passage on trypticase soy broth at $28^{\circ} \mathrm{C}$. All challenged lobsters died exhibiting heavy infections with $A$. viridans (var.) homari

\begin{tabular}{|lcc|}
\hline $\begin{array}{l}\text { MTD following } \\
\text { 1 passage }(\mathrm{d})\end{array}$ & $\begin{array}{c}\text { MTD following } \\
\text { 8 passages }(\mathrm{d})\end{array}$ & $\begin{array}{l}\text { MTD following } \\
\text { 16 passages }(\mathrm{d})\end{array}$ \\
\hline $9.6 \pm 2.4$ & $11.1 \pm 2.6$ & $13.7 \pm 2.1$ \\
\hline
\end{tabular}

question remained as to whether the agglutinin was not adsorbed or whether it was actually adsorbed, but was ineffective. The lack of any reduction in the agglutinin titre of the hemolymph serum adsorbed with the virulent Rabin's strain (Table 5) showed that the agglutinin was not adsorbed by the virulent strain, but it was adsorbed and fully removed by the avirulent strain. Interestingly, in these trials the agglutinin activities against the Brevibacterium reference strain or the rabbit red-blood cells were reduced somewhat, but not completely removed.

In an attempt to discover the nature of the factor(s) inducing virulence, avirulent Strains 88A, 88B, 37R and ATCC 10400 were transferred from $18 \mathrm{~h}$ TSB cultures to normal lobster hemolymph serum that had been heated at $56^{\circ} \mathrm{C}$ for $1 \mathrm{~h}$, centrifuged at $30000 \times g$ for $20 \mathrm{~min}$ at $5^{\circ} \mathrm{C}$ to remove precipitates, and then sterilized by viving lobsters by hemolymph smear and TSB culture at the end of the 42 day trial period showed no $A$. viridans (var.) homari in the hemolymph of most of the lobsters. Two lobsters injected with ATCC 10400 and 3 lobsters injected with Strain 37R, however, did show a few tetrads in the TSB cultures, but none by hemolymph smear, thereby confirming the low level of infection.

This trial was repeated using lobster hemolymph serum heated for a shorter time at a higher temperature $\left(30 \mathrm{~min}\right.$ at $65^{\circ} \mathrm{C}$ instead of $1 \mathrm{~h}$ at $\left.56^{\circ} \mathrm{C}\right)$. The strains grown in the sterile serum and used to challenge 10 lobsters each with approximately $1 \times 10^{6} \mathrm{cfu} \mathrm{ml}^{-1}$ $\left(1 \mathrm{ml} \mathrm{kg} \mathrm{BW}{ }^{-1}\right)$ were 88B, 37R and ATCC 10400. No deaths from gaffkemia were recorded, and at the end of the experiment all lobsters were examined by hemolymph smear and TSB culture; none of the lob-

Table 5. Serum adsorption of Aerococcus viridans (var.) homari: (A) live virulent Rabin's strain and (B) live avirulent American Type Culture Collection (ATCC) 10400. Lobster Homarus americanus hemolymph agglutination with adsorbed and unadsorbed serum. Representative results from several identical trials

\begin{tabular}{|lccc|}
\hline \multicolumn{3}{|c|}{ Agglutination Titres } \\
Adsorption & Brevibacterium & ATCC 10400 & $\begin{array}{c}\text { Rabbit red blood cells } \\
(1 \% \text { v/v in 3\% NaCl })\end{array}$ \\
\hline (A) & & & \\
Zero & 32 & 16 & 16 \\
1st adsorption & 32 & 16 & 16 \\
2nd adsorption & 32 & 32 & 16 \\
3rd adsorption & 32 & 16 & 16 \\
(B) & & 16 & 16 \\
Zero & 16 & Negative & 8 \\
1st adsorption & 16 & Negative & 2 \\
2nd adsorption & 16 & Negative & 4 \\
3rd adsorption & 8 & & \\
& & & \\
\hline
\end{tabular}


sters were shown to be Aerococcus viridans (var.) homari positive. Although these trials were preliminary with regard to determining the specific nature of the virulence inducing factor(s), the results indicate clearly that the factor(s) in the lobster hemolymph serum responsible for inducing virulence in avirulent A. viridans (var.) homari strains is (are) heat labile.

\section{DISCUSSION}

Smith (1984) stated that the synonymous terms pathogenicity and virulence are multifactorial in nature, and for a microorganism to be considered pathogenic, it should, as a minimum requirement, fulfill the following 3 of his 5 terms, notably: (1) multiply in the environment of the host's tissues; (2) resist or interfere with the host's defence mechanisms; and (3) cause damage to the tissues of the host.

Smith's other 2 terms are related to surface infections and entry that do not apply to Aerococcus viridans (var.) homari because it is wholly lacking in invasive powers (Stewart et al. 1969). It gains entry through opportunistic breaks and ruptures in the lobster integument.

As summarized by Stewart (1984, 1993), upon entry the numbers of virulent Aerococcus viridans (var.) homari in the hemolymph tend to decline over the initial $48 \mathrm{~h}$ period, largely as a result of phagocytosis. The bacterium accumulates initially in the hepatopancreas and cardiac tissue where it multiplies rapidly and spills over into the hemolymph. Phagocytosis, however, does not result in the death of the pathogen, which continues to multiply, but rather in a massive decline in hemocyte numbers, thereby impairing the clotting capacity of the hemolymph and heightening the possibility of fatal hemorrhages. The pathogen grows at the expense of free glucose, generated from the glycogen stores, and nonprotein nitrogen of the lobster. The numbers of bacteria routinely are of the order of $1 \times 10^{9} \mathrm{~g}^{-1} \mathrm{or} \mathrm{ml}^{-1}$ of hepatopancreatic tissue and hemolymph, respectively, and $1 \times 10^{8} \mathrm{~g}^{-1}$ for cardiac or skeletal muscle tissue. Declines in adenosine triphosphate, glycogen, circulating glucose and non-protein nitrogen suggest that death occurs from a massive dysfunction of the hepatopancreas. These characteristics fully meet the requirements of the 3 terms drawn from Smith (1984).

Our studies illustrate the relatively wide range of MTD and, thus, capacities of freshly isolated strains to cause death in the lobster host when tested under identical circumstances. As expected, maintenance on laboratory medium altered these capacities, substantially extending the times it took many of the strains to kill their hosts. About half of the strains tested after a $3 \mathrm{yr}$ period on laboratory media were not capable of killing all of the individual hosts, and 1 strain had become completely avirulent.

The loss of the pathogen's capacity to form capsules, the development of susceptibility to lobster hemolymph serum agglutinin, and reduced capacity to grow in lobster hemolymph serum adequately account for the loss of virulence. This is reinforced by the data, showing that restoration of virulence (through growth in hemolymph serum) coincides with a restoration of the capsule and the elimination of the susceptibility of the pathogen to the hemolymph serum agglutinin. The fact that the virulent strains are phagocytosed without adsorbing the serum agglutinin indicates that, in this instance, the agglutinin does not have an opsonizing role (Cornick \& Stewart 1968, Paterson et al. 1976, Johnson et al. 1981). Presumably, the presence of the capsule protects the pathogen against the killing action within the phagocytes. As the avirulent strains are susceptible to the agglutinin, it is probable that for them it has an opsonizing role comparable to that demonstrated for sheep red-blood cells (Paterson \& Stewart 1974). Since the agglutinins appear to be associated with the circulating and fixed phagocytes (Cornick \& Stewart 1978), it is likely that the agglutinins also contribute to the elimination of the avirulent bacteria within the phagocytes.

Smith (1989) emphasized the importance of the rate of growth in pathogenicity; where growth is slow, host defences are more able to cope. The poorer growth of certain avirulent strains in lobster hemolymph serum, coupled with their susceptibility to the agglutinin, must be important aspects contributing to their avirulence. As Kasper et al. (1990), among others, state, capsulated organisms are more virulent than unencapsulated variants, and it is believed that bacterial capsules are antiphagocytic. Although apparently true for the Type III Group B streptococci central to their review, this suggested antiphagocytic principle does not appear to apply to the capsulated, virulent strains of Aerococcus viridans (var.) homari, as these are readily phagocytosed. The conclusion by Barnes et al. (2003), that the capsules of Streptococcus iniae could be interfering with immune serum killing, may be more relevant in suggesting a role for the capsule of $A$. viridans (var.) homari.

Interestingly, structural studies on the capsular polysaccharide of Aerococcus viridans (var.) homari revealed that it has some unique features. Hermansson et al. (1990) have shown that it has a tetrasaccharide repeating unit with 3 different acidic sugars, 2 of which have not been found to be components of any other naturally occurring material. The extent to which the uniqueness of this polysaccharide contributes to making this bacterium a specific pathogen for lobsters poses an intriguing question. 
Virulence is not lost readily or rapidly, even by strains which had lost it previously, as shown by trials with Aerococcus viridans (var.) homari (ATCC 10400). After virulence had been restored there was no appreciable change in virulence in the short term, despite 16 passages in laboratory medium at an elevated temperature.

While growth of avirulent strains of the pathogen in normal lobster hemolymph serum resulted in restoration of virulence, growth in heated serum failed to do so. The factor(s) inducing virulence are heat labile, probable nutritional inducers of the long-lasting phenotypic response.

Acknowledgements. We thank Paul E. Kepkay and Timothy G. Milligan for reviewing a draft of the manuscript, and Stephen J. Smith for statistical advice and assistance.

\section{LITERATURE CITED}

Barnes AC, Young FM, Horne MT, Ellis AE (2003) Streptococcus iniae: serological differences, presence of capsule and resistance to immune serum killing. Dis Aquat Org 53: 241-247

Cornick JW, Stewart JE (1966) Microorganisms isolated from the hemolymph of the lobster Homarus americanus Milne Edwards. J Fish Res Board Can 23:1451-1454

Cornick JW, Stewart JE (1968) Interaction of the pathogen Gaffkya homari with natural defense mechanisms of Homarus americanus. J Fish Res Board Can 25:695-709

Cornick JW, Stewart JE (1973) Partial characterization of a natural agglutinin in the hemolymph of the lobster, Homarus americanus. J Invertebr Pathol 21:255-262

Cornick JW, Stewart JE (1978) Lobster (Homarus americanus) hemocytes: classification, differential counts, and associated agglutinin activity. J Invert Pathol 31:194-203

Fisher WS, Nilson EH, Steenbergen JF, Lightner DV (1978) Microbial diseases of cultured lobsters: a review. Aquaculture 14:115-140

Hermansson K, Kenne L, Lindberg B, Arie B, Brown RG, Stewart JE (1990) Structural studies of the capsular polysaccharide from Aerococcus viridans var. homari. Carbohydr Res 208:145-152

Johnson PT, Stewart JE, Arie B (1981) Histopathology of Aerococcus viridans var. homari infection (gaffkemia) in the lobster, Homarus americanus, and a comparison with histological reactions to a gram-negative species, Pseudomonas perolens. J Invertebr Pathol 38:127-148

Editorial responsibility: Timothy Flegel (Editor),

Bangkok, Thailand
Kabat EA, Mayer MM (1961) Experimental immunochemistry, 2nd edn. Thomas, Springfield, IL

Kasper DL, Wessels MR, Rubens CE (1990) Role of the capsular polysaccharide of Type III Group B streptococci in virulence. In: Ayoub EM, Cassell GH, Branche WC, Henry TJ (eds) Microbial determinants of virulence and host response. American Society for Microbiology, Washington, DC, p 113-121

Lauffer MA, Swaby LG (1955) The size, shape and hydration of lobster hemocyanin. Biol Bull 108:290-295

Paterson WD, Stewart JE (1974) In vitro phagocytosis by hemocytes of the American lobster (Homarus americanus). J Fish Res Board Can 31:1051-1056

Paterson WD, Stewart JE, Zwicker BM (1976) Phagocytosis as a cellular immune response mechanism in the American lobster, Homarus americanus. J Invertebr Pathol 27: 95-104

Pearse AGE (1961) Histochemistry: theoretical and applied, 2nd edn. J\&A Churchill, London

Sindermann CJ (1990) Principal diseases of marine fish and shellfish, Vol 2. Diseases of marine shellfish, 2nd edn. Academic Press, New York

Sindermann CJ, Lightner DV (eds) (1988) Disease diagnosis and control in North American marine aquaculture, 2nd edn. Elsevier, Amsterdam, p 232-235

Smith H (1984) The biochemical challenge of microbial pathogenicity. J Appl Bacteriol 47:395-404

Smith H (1989) The mounting interest in bacterial and viral pathogenicity. Ann Rev Microbiol 43:1-22

Snedecor GW, Cochran WG (1973) Statistical methods, 6th edn. Iowa State University Press, Ames

Sparks AK (1981) Bacterial diseases of invertebrates other than insects. In: Davidson EW (ed) Pathogenesis of invertebrate microbial diseases. Allanheld, Osmun \& Co, Totowa, NJ, p 323-363

Stewart JE (1984) Lobster diseases. Helgol Meeresunters 37: $243-254$

Stewart JE (1993) Infectious diseases of marine crustaceans. In: Couch JA, Fournie JW (eds) Pathobiology of marine and estuarine organisms. Advances in Fisheries Science. CRC Press, Boca Raton, FL, p 319-342

Stewart JE, Rabin H (1970) Gaffkemia, a bacterial disease of lobsters (Genus Homarus). In: Snieszko SF (ed) A symposium on diseases of fishes and shellfishes. Special Publication No 5. American Fisheries Society, Washington, DC, p 431-439

Stewart JE, Cornick JW, Spears DI, McLeese DW (1966) Incidence of Gaffkya homari in natural lobster (Homarus americanus) populations of the Atlantic region of Canada. J Fish Res Board Canada 23:1325-1330

Stewart JE, Dockrill A, Cornick JW (1969) Effectiveness of the integument and gastric fluid as barriers against transmission of Gaffkya homari to the lobster Homarus americanus. J Fish Res Board Canada 26:1-14

Submitted: July 22, 2003; Accepted: October 27, 2003

Proofs received from author(s): July 6, 2004 